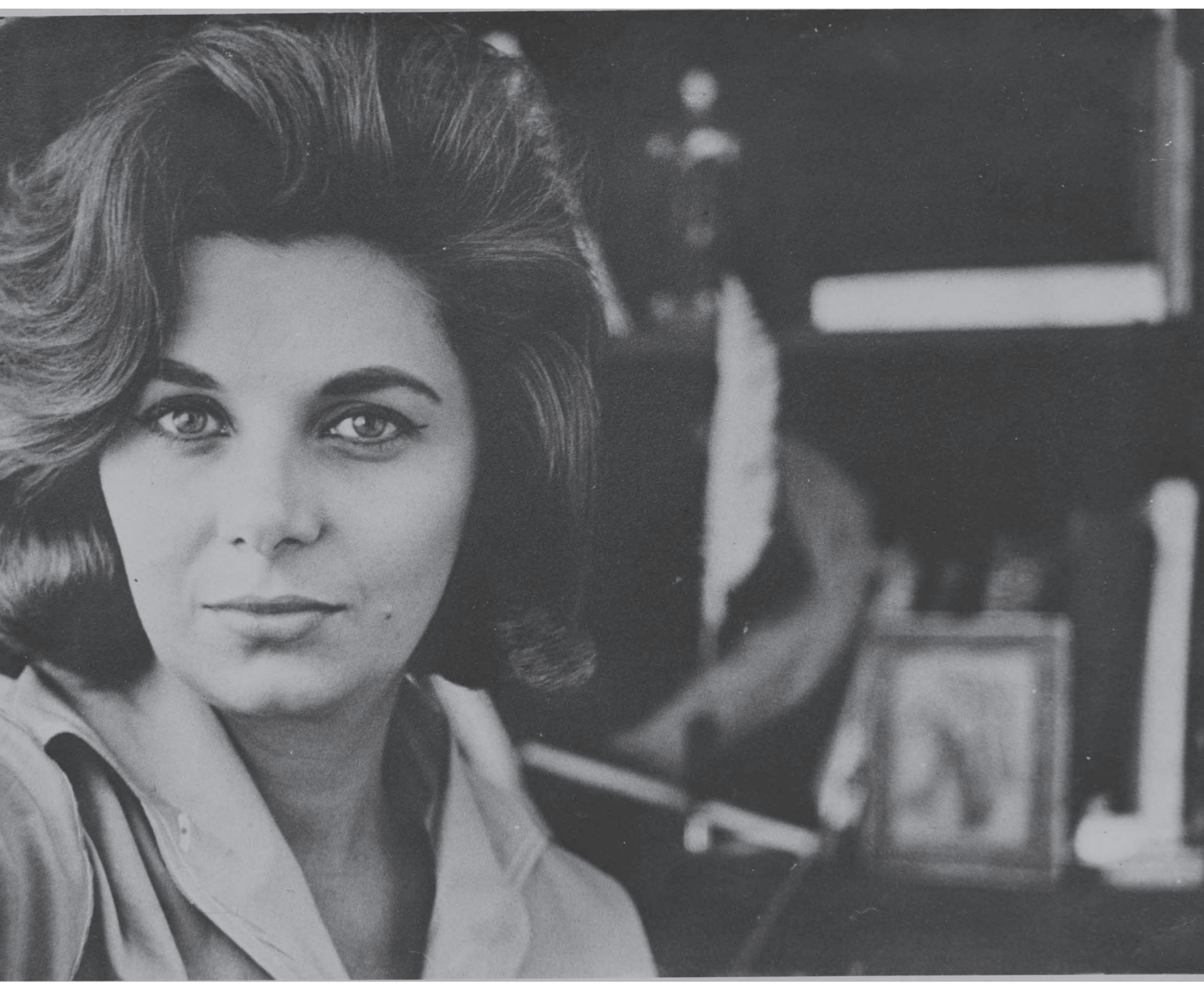




\section{Dossiê Lupe Cotrim}

\section{Lupe Cotrim, 40 anos depois}

Quarenta anos depois de sua morte, a professora e poeta Lupe Cotrim é homenageada neste exemplar da revista $A R S$ com um dossiê especial. Um dos nomes de destaque da poesia brasileira da década de 1960, Lupe integrou a equipe de professores-fundadores desta Escola de Comunicações, lecionando Estética e Pensamento Filosófico. Sua atuação notável diante dos desafios da recém-criada unidade da USP e, ao mesmo tempo, da conjuntura política adversa por que passava o país, levou os estudantes a darem o seu nome ao Centro Acadêmico da escola após sua morte prematura, aos 36 anos, em 1970. "A sua condição de escritora, poeta, professora formada em filosofia lhe permitiu enfrentar, melhor que ninguém", aqueles desafios, especialmente "na agitação de 1968", lembrou o professor Ismail Xavier, em seminário realizado, em março de 2010, no Instituto de Estudos Brasileiros, depositário do acervo da professora-poeta. "Ela foi uma liderança decisiva naquela conjuntura, e seu curso representou a experiência mais densa, do ponto de vista intelectual e político, daquele ano".

$\mathrm{O}$ dossiê que se segue traz textos resultantes do seminário realizado no IEB-USP, além de fotografias e uma seleção de poemas da autora, que deixou sete livros de refinada poesia lírica, o último deles, Poemas ao outro, triplamente premiado. 
“0 dúplice"

\author{
Ser poeta \\ é meu resíduo \\ de tristeza \\ ao não ser triste. \\ A dor que deveras sente \\ é a que sinto. \\ E o que vemos a mais \\ nas coisas simples \\ os subterrâneos cavados \\ nas doces superfícies \\ é nosso modo de unir \\ o solto e o que resiste.
}

Viverá como vivo.

O tempo e seu assalto

não nos caberá

fora desse pacto

sonoro e terrível;

a morte é o que não falo.

Da verdade sabemos

a umidade na carne

e o dorso embaçado.

Em nossa gula

tudo se avizinha

na imagem que degulete

mesmo os ossos da fuga.

Cúmplices,

o poeta e eu

nos salvamos do crime.

E do outro que somos

ainda por dizer

devoramos a fome.

[Do livro Poemas ao outro, 1970] 
“Memória barroca"

A Carlos Drummond de Andrade

"É preciso fazer um poema sobre a Bahia...

Mas eu nunca fui lá.”

Alguma poesia

Uma cola negra escorre

das calçadas, e o mar escurece

no pigmento do rosto.

Uma fratura na pedra; e mais outra.

Estátua que se ergue

ou entranha que se mostra.

$\mathrm{O}$ saveiro furta às águas

a sumária riqueza dos peixes

e no farol se acende

a história ameaçada; nem tudo será

resíduo e paisagem. A couraça

urbana acintura a nova cidade

cinza e domesticada.

O visível de hoje, que se descobre

entre a poeira dourada

há de fechar-se: em escrutínios

de marfim e tartaruga

em barras de memória

barroca e inapelável.

O ouro, o entalhe,

a torre, a nave; o forte

pontiagudo da indignação

passada, presente maciço,

ombro erguido contra o mar

amortecido de altares.

A areia grossa, a onda oleosa

que se apruma por ladeiras lentas

nos passos de quem rediz

os caminhos de volta

- cada pedregulho já é outrora.

Entre corredores de redes

a beleza se aconchega 
madura e esplêndida:

no umbral dos solares

é ela quem nos vê

altiva e derradeira.

Soerguidos pela brisa

imergimos nos meandros do mar

e na paisagem da magia:

mas rasga-se entre as mãos

a miséria sem névoa

- é ela que nos penetra.

II.

Homens cercados de águas

por todos os lados:

perfis Alagados.

Numa vida em que o futuro

não é o primeiro rumo,

lá em Alagados.

Uma criança no detrito

inventa seu edifício

lá em Alagados

e o corpo insiste sobre o lixo uma sentença passada.

Confins Alagados.

$\mathrm{O}$ rádio noticia o ato

lá em Alagados.

Para homens sem enxada

lá de Alagados.

O silêncio é o silêncio

lá em Alagados.

Uma criança no detrito

inventa seu edifício

lá em Alagados

que sustenta casa a casa

enfins Alagados.

Uma árvore de natal

lá em Alagados

aponta Cristo à espera 
- atento, Alagados.

Uma mulher varre o lixo

lá em Alagados

morando sobre os detritos

lá de Alagados.

O homem é ator do homem

lá em Alagados

representando a cidade

senfins Alagados.

Tudo é um deserto de águas

lá em Alagados, consumindo seus naufrágios.

Ai, Alagados.

III.

Cada pedregulho já é outrora.

A beleza se aconchega

madura e esplêndida

no umbral dos solares,

é ela quem nos vê

altiva e derradeira.

Seduzidos pela brisa

mergulhamos na poeira dourada

e nos azuis incontáveis:

mas rompe-se entre os olhos

uma miséria sem trégua

- essa é a nossa treva.

Salvador, 1968

[Do sétimo livro, Poemas ao outro, 1970] 
“À margem da poesia"

Rilke estava enganado:

um poeta é um poeta

e vive sem fazer versos.

Por outras razões se morre

e as forças de viver

são mais cegas, são mais ágeis

que a direção de morrer.

Maiakovski se matou

podendo fazer poesia

e pagando seus impostos.

Como? Onde? Para quem?

Aqui, ali, pouco importa,

em tudo a mentira sobra;

morreu na boca de um poema

o pulso farto de versos.

Outros também se calam

na fímbria solta das sílabas

todo o lirismo nas mãos

corpo exposto a faca e bala

na altivez de perfil

por onde olha a poesia, sozinha, sua própria véspera.

Se morre por outros rumos

aquém e além do dizer

e do poeta é a sina

não viver só de palavra

mas do chão, da cerca, da água

onde germina em silêncio

o que desabrocha a fala.

Versos se podem calar;

há coisas que não se calam

porque caladas, veneno

pior que o aço da espada.

Matando o irmão por dentro

dobrando o porte - a verdade

esgar de consentimento. 
$\mathrm{O}$ vivo é antes do verso.

Urgente é abrir seus olhos

e as cortinas lacradas.

$\mathrm{O}$ verso, sim, mas depois

das razões de não morrer.

E assim fazendo, dizer.

Se vive com fome e sede

com amor estilhaçado

analfabeto, amarrado,

com chumbo dentro do ventre

sem sexo, luz, alvorada,

um homem vive de pouco

resiste às vezes de nada.

Das desrazões, irrazões

porque se venha a viver

há um poeta sem versos

que é poeta a valer

e sobrevive. De gula

talvez de usura,

confiança em quem ignora,

no cego, no surdo-mudo.

Rilke estava enganado.

Um poeta suicida

anunciou vento adentro

- o romantismo acabou.

O que estava por detrás

lá nos fundos da poesia

é que mata. E o matou.

Um pano em volta do rosto

muitos espreitam, se calam.

Mas além de ultraje e mito

numa resistência inteira

um poeta ainda espera

no calcanhar de seu grito. 
Faz seus versos, e sem fazê-los

permaneceria vivo.

[Do sétimo livro, Poemas ao outro, 1970]

\section{“Monólogo l”}

Hei de inventar amor, ávida e atenta.

Amor de ser a outro que é demais

o amor que em coisas hoje se alimenta.

A manhã é cerrada de momentos

que hábeis mãos inventam em seu provento;

inventar o que o íntimo não fala,

curvando-se à pressão de outros inventos.

Hei de inventar amor num desafio

às mais concretas frases, aos dias úteis,

amor de ser a outro que é demais

ter um mundo por dentro desprovido.

[...]

\section{“Diálogo l”}

Ser transparente

é quase um suicídio,

um transbordar de si

perdido, ir a outro de nós

que nos retém, apagado

o sentido.

[...]

[Do sexto livro, Inventos, 1967] 
“João, fragmentos"

I.

O que é nosso, João, entre o teu e o meu

o que separa em posse

a nossa solidão?

Não sei. Não sei

o que era de mim

no que te encontrei.

Hesito entre o inscrito

e o que me vem às mãos:

tenho pouco do perto.

Antes creio

no que ainda terei

porque desperto.

Vês o mundo, João,

como quem não sabe

ou enxerga em vão.

É um ver qualquer,

o teu, sem detalhe ou magia,

e devo a teu olhar

o segredo ondulado

onde o mundo principia.

II.

Há países mordidos

e uma língua de metal

astuta e imprevisível

dilacerando o homem

em sua própria criança.

$\mathrm{O}$ que faremos, João?

[...]

Enquanto penso, existes

com fomes divergentes.

Franzimos as sobrancelhas

para o que alguns fazem

de nossa bandeira.

Apesar, João: 
III.

Enquanto, João, alegria eu quero apesar da guerra.

Para nós e em volta

medula de resistência

em nossa presença.

Ladeando a fome, ladeando a morte

de Biafra às vizinhanças

consumir alegria

de manter-se vivo

apesar e contra isso.

Se o gesto é escrito

e perduras analfabeto,

se o pão é farto

e teu estômago descalço

se alguns vão à lua

no esplendor da técnica

e prossegue a miséria

em sua chaga satélite,

alegria, João.

Por um outro dia

necessitamos fazer parte

do que nele principia.

[...]

Alegria pela manhã

que contra hoje vai chegar,

sub-versiva, sub-vertida

sub-metida.

Alegria de nós, em nosso intento:

alegria como é viva

uma pessoa viva.

[Do sétimo livro, Poemas ao outro, 1970] 
Porque a pedra

está fora do tempo

e eu por dentro;

porque a terra se desata,

vegetal,

e a mim falta

esse fôlego verde,

em tênue movimento;

porque entre raiz e folha

o animal salta,

elástico, e desconheço

liberdade tão alta;

porque mineral e vegetal

uma floresta é segredo

aberto ao animal

e em mim se enlaça

pelos cipós do medo

- sei-me de outra espécie.

Em que sou fraco. E antes

de tudo - breve.

Mas nesta extensão tão plena

é que mais compreendo.

[...]

E são rochas de leões

marés de outono

folhas alçando-se no arrojo

dos pássaros, répteis

em curvas de diamante,

montanhas côncavas, murmurando,

florestas em ondas, sobre as águas

as distâncias são formas

- corpo de estrela, impulso de planície,

a morte é apenas uma flor

vermelha, que passa no vento

[...]

e em tudo estou presente, simultâneo,

o horizonte a meus pés, como um riacho doce. 
Olhando dentro de mim,

de dentro da natureza,

eu a refaço - e invento a beleza.

[Do quinto livro, O poeta e o mundo, 1964]

\section{“Última paisagem”}

Quando eu morrer,

se morrer,

quero um dia de sol,

denso, cintilante,

escorrendo-me pelo corpo

seus dedos quentes.

E quero o vento,

um largo vento dos espaços,

que me respire e me arrebate

no seu fôlego,

por outros continentes.

E quero a água,

violenta, fria, palpitante,

possuindo-me a alma

a transbordar dos poros.

Se nenhum amor me resguardar

em seu abraço

a dar-me sensação

de que possuo e pertenço

quero pegar a vida

palmo a palmo,

traço a traço,

num dia esfuziante de azul

com o mar na boca e nos braços.

Quando eu morrer,

se morrer,

eu que renasço a cada momento,

criando íntimos laços

por toda natureza, 
eu que perduro no eterno

da intensidade,

quero morrer assim:

os olhos na distância

do entendimento

e o corpo penetrando na beleza,

passo a passo.

Meu fim transformado em luz

dentro de mim.

[Do quinto livro, O poeta e o mundo, 1964] 